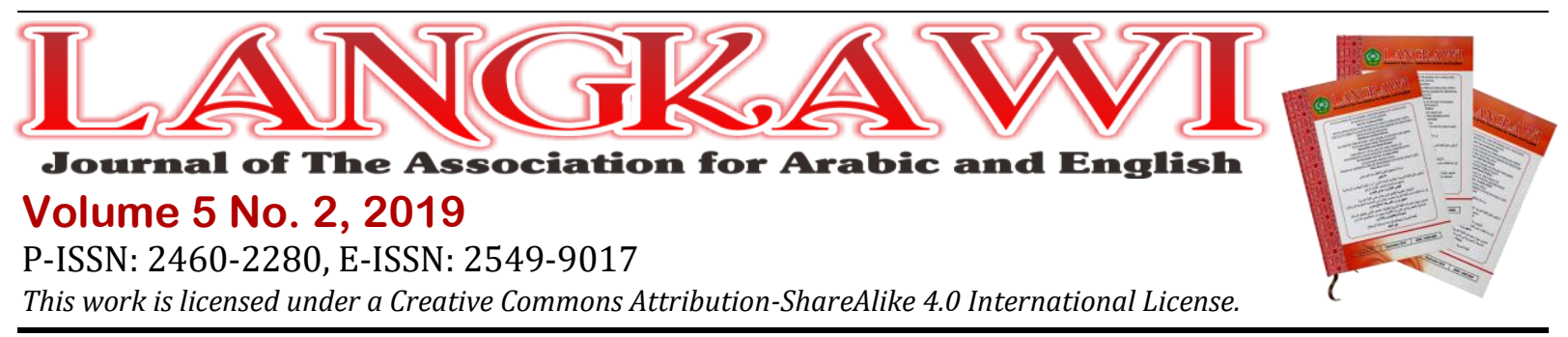

\title{
Conversational Implicature Function between Mitsubishi Car Salesperson and Consumers in Padang
}

\author{
Betari Anindya1, Ike Revita², Gusdi Sastra ${ }^{3}$ \\ ${ }^{1}$ Andalas University, Indonesia. E-mail: betarianindya@gmail.com \\ ${ }^{2}$ Andalas University, Indonesia. E-mail: ikerevita@hum.unand.ac.id \\ ${ }^{3}$ Andalas University, Indonesia. E-mail: sastrabudaya84@ gmail.com
}

\section{ARTICLE INFO \\ Keywords: \\ Conversational \\ Implicature; Car \\ Salesperson; Consumers}

How to cite:

Anindya, B., et al. (2019).

Conversational

Implicature Function

between Mitsubishi Car

Salesperson and

Consumers in Padang.

Langkawi Journal of The

Association for Arabic and

English, 5 (2) 140-151.

DOI:

http:/ / dx.doi.org/10.31 332/lkw.v5i2.1312

\begin{abstract}
Implicature is one of the important language studies. It is because implicature can provide explanations of linguistic facts that cannot be explained by other linguistic theories. This study aims to explain the function of implicature, which is found in the conversation between Mitsubishi car salesperson and consumers in Padang. The data are the utterances containing implicature between Mitsubishi car salesperson and consumers in Padang. To collect data, researchers used the observational method. This method was realized by using basic techniques and advanced techniques. The recording was a basic technique, while nonparticipate observation, recording, and note-taking were the advanced technique. The results indicated that there are three pragmatic functions in the conversation of Mitsubishi car salesperson with consumers in Padang. They are assertive functions such as stating, explaining, and expressing opinions; directive functions such as demanding; and commissive functions such as advocating, promising, and offering. From the several implicature functions above, the most dominant function is assertive for stating, explaining, and expressing opinions. Some of these conversational functions tend to be used as expressing and explaining.
\end{abstract}

\section{Introduction}

The concept of pragmatics was first put forward by Morris in 1938. He had great attention to semiotic science (sign systems) and distinguished three fundamental concepts in semiotics, namely syntax, semantics, and pragmatics (Revita, 2013). Levinson (1993) explains that pragmatics is the study of language relations with the context that underlies the explanation of language. Meanwhile, Leech (1993) suggests that pragmatics studies meaning in relation to the speech situation. He states that pragmatics study how language is used in communication, and how pragmatics investigate meaning as context, not as something abstract in communication. Wijana (1996) states that pragmatics is a branch of language science that studies the structure of language externally, namely how linguistic units are used in communication. Based on that, then to understand the use of language we are also required to understand the context that accommodates the use of the language. 
One branch of linguistics that studies meaning based on the context that accommodates the use of language is implicature. The concept of conversational implicature was first put forward by Grice (1975) in his article entitled "Logic and Conversation". Grice (1975) states that implicature is a speech that can imply propositions that are not part of the speech. Meanwhile, Levinson (1993) suggests that implicature is one of the most important ideas or thoughts in pragmatics. In other words, implicatures can explain explicitly how to express speech more than what is said.

Implicature as one aspect of the pragmatic study has the primary concern in the use of language to learn intent or speech according to the context (Allott, 2018; Kravchenko, 2017; Lubis, 2017; Slocum, 2016). Igwedibia (2017) has researched 'Grice's Conversational Implications: A Pragmatics Analysis of Selected Poems of Audry Lorde' to find out the extent to which conversational implicature and the cooperation maxim can be applied in reading the poem of the Audry Lorde. Furthermore, Wahyuningsih (2017) examined the "Implication of Conversation in Stand-Up Comedy $4 "$ to gain an in-depth understanding of the types of implicature, the nature of implicature, and the maximal cooperation in Stand-Up Comedy 4 Indonesia. It explains that research on pragmatics, especially in aspects of implicature, increasingly attracted the attention of language researchers. This is to find out the implicit meaning behind what is said.

Based on this, the researcher is interested in researching the function of implicature. In this study, the author focuses on discussing the function of conversational implicature between Mitsubishi car salesperson and consumers in Padang. The salesperson in carrying out sales and marketing activities, of course, also uses language in communication with consumers. Mitsubishi car salesperson in Padang (starting now abbreviated as PMM) in communicating use language as a medium to deliver ideas to attract consumers' attention to products sold or marketed. In conducting conversations with consumers, sometimes the intention that is spoken has direct and indirect meaning. It is the same as the usual conversation, but the context and the things discussed will be different. In general, conversations that also occur often violate the rules of conversation. It resulted in something that is implicated in the use of language. The implications also have a relationship between something else in the context of broad communication.

The use of implicature in the dialogue between Mitsubishi car salesperson and consumers is assumed to be unique. It is in line with the way how the salesperson attracts the consumer's intention to buy the product. Implicature can be one strategy applied for the customers are persuaded. Even the use of implicature may camouflage reality. Thus, the goodness of the product of this brand can be highlighted. The Mitsubishi warehouse produces several types of Mitsubishi brand cars for personal (family) or commercial or business use by the company. The company is engaged in the sale of various types of vehicles brand Mitsubishi, both family vehicles (types of Lancer, Grandis, Maven, Kuda, Pajero, and Triton). Meanwhile, the types of cars for commercial use include Mitsubishi Fuso, L300, L200, and Super Pick Up. Moreover, the Mitsubishi Company is engaged in the sale of parts and workshop centers for servicing, maintaining, and repairing all types of Mitsubishi brand vehicles. 
Currently, the Indonesian Mitsubishi company is getting a positive response from the public to one of its products, the Mitsubishi Xpander (Prayogi, 2018). It means that with the presence of Mitsubishi Xpander products, the Mitsubishi brand has become very popular in public. The high public interest in one of Mitsubishi's products is one of the results of the salesperson's efforts to sell and promote the company's products. Based on this, the researcher is interested in looking at the language phenomena that occur between Mitsubishi salesperson and consumers. For this reason, it is necessary to research to understand more about the function of implicit meanings in PMM's speech with consumers in Padang.

\section{Method}

The research used descriptive qualitative research with case study method. The data were pragmatic speech between PMM and $\mathrm{K}$ containing implicature. According to Sudaryanto (2015), the data source is divided into two, namely locational and substantive data sources. Locational data sources were Mitsubishi car salesperson and consumers; meanwhile, substantive data sources were all of the text conversations between Mitsubishi car salesperson and consumers at PT. Andalas Berlian Motors Padang with several branch companies located on Jl. Bypass, Niaga, and Khatib Sulaiman in Padang. Data collection was carried out at the three places with the procedure that the head office provided for data collection used the observation method. The following were some steps that the researcher has taken in providing data; the first step that the researcher did was tapping the conversation that took place between the sales clerk and the consumer using the tapping technique, which was part of the basic technique of the observation method. The second step was followed by listening and paying attention to the use of language that occurs between PMM and consumers which used non-participating observation methods. The third step was filtering data by grouping it into the types of implicature contained in the conversations that occur as well as taking note of the results of the conversational data by using the recording and taking note techniques. The method used in analyzing the data was the identity method. The determinants of the method were referential, translational, and pragmatic methods. Meanwhile, the analysis was done by classifying speech into data based on Searle's (1969) speech act theory to express the logical function of the speech.

\section{Findings and Discussion}

Pragmatic function, according to Kridalaksana (2008), is a relationship between something in the context of broad communication. Furthermore, this function will appear in a speech that has implications because implicature is very carefully related to the context. In playing its role, the pragmatic function must violate the cooperation maxim in the speech act between the speaker and the opponent so that an implicature is created. Based on this, the pragmatic function of speech implicature has a close relationship with speech acts.

To find out the function of an implicature speech function that is used by speakers toward the opponents in a communication context, an analysis is needed. Meanwhile, the analysis carried out is a logical function analysis that analyzes the relationship between elements of language as a result of the communication context. In conducting this analysis, Searle (1969) uses the language function theory as 
described above. For Mitsubishi car saleswoman is abbreviated as PMMP, Mitsubishi car salesman is abbreviated as PMML, female consumers are $\mathrm{KP}$, male consumers are KL, and car insurance salesperson become PAM. Result of the analysis of conversational implicature functions between Mitsubishi car salesperson and consumers as follow as:

\subsection{Assertive Function}

A certain function is a speech function that binds speakers to the truth following real facts. Based on the analysis of conversations by Mitsubishi car salesperson with consumers in Padang, certain functions were found in the form of expressing, explaining, and giving an opinion.

\subsubsection{Expressing}

Expressing is one of the conversational implicature functions that clarifies, informs, and explains something following facts (KBBI, 2008). Some functions of expressing are found in the conversation of Mitsubishi salespersons are as follows:

\section{Dialog 1}

KL : Kalau nio saketek angsurannyo, sagituyo DP nyo?

'If I want a small installment of that payment, is that the down payment?'

PMMP : Iyo sagitu DPnyo Pak, kalau ultimate DP 80, angsurannyo 5 juta Pak salamo 4 tahun.

'Yes, that is the down payment, Sir, the down payment of the ultimate is IDR $80,000,000$, and the installment payment is IDR $5,000,000$ for 4 years, Sir'.

KL : Kok dapek ndak lamo baurusan jo Ibuk do kan, jo urang kreditkredit ko.

'Hopefully, it is not a long time to deal with you and with the credit people.'

PMMP : Urusannyo kan ka leasing Pak, ndak ka showroom lai do.

"The administration is with the leasing, Sir, not with the showroom anymore.'

KL : Iyo yang kayak-kayak tu ndak lamo wak baurusan lai do.

'Yes, the administration like that, we will not belong for dealing'.

In this conversation, KL and PMMP discuss the installment period of Mitsubishi Xpander that wants to be bought by KL. KL requests that PMMP provide a fast installment period. KL is a householder. As the head of the family, KL has much responsibility for family finance. Therefore, KL wants a fast credit period. Through the implicature sentence, KL tries to convey its intention so that PMMP can provide a fast credit period.

Negotiations that occurred between KL and PMMP above contained the function of assertive implicature, which is expressing. According to (KBBI, 2008), expressing that it is one of the conversational implicature functions that clarifies, informs and explains something according to the facts. The utterance 'Kok dapek ndak lamo baurusan jo Ibuk do kan, jo urang kredit-kredit ko' is a sentence that indirectly explains that KL wants a fast credit period. Through the implicature, KL 
tries to explain or inform the PMMP of its objections to the time offered by PMMP. Based on this, the speech contains the function of assertive implicature, namely expressing.

Dialogue 2

K : Oh gitu. Jadi, kalau mode tu beko tu lai masuak asuransi Buk?

'Oh, I see. So, if it is like that, will the car get insurance, Mam?'

PMM : Kok kredit aman, beda jo cash Pak.

'If the credit insurance is ok, but it's different from cash'

$\mathrm{K} \quad$ : Asuransinyo lai all risk, Buk?

'All risk insurance, isn't it, Mam?'

PMM : Lai, All risk, Pak.

'Yes, all risk, Sir'

The conversation above discusses car insurance. In the conversation, KL worried about the safety of the vehicle he is going to buy. For this reason, he asks about the vehicle insurance to PMMP. The data shows that KL asks about the insurance of the car. Next, the PMMP responds to the KL's question with the utterance 'the insurance is ok, sir,' which this utterance has an implicit meaning.

After analyzing the conversation, the function of assertive implicature is expressing. Through the implicature speech, it appears that PMMP tries to provide information or explain that the vehicle of $\mathrm{K}$ will get insurance. The word 'ok' means free from danger. The word 'ok' refers to insurance, which is being discussed in the conversation above. By using the word 'ok', the PMMP implies that the vehicle gets insurance.

\subsubsection{Explaining}

Explaining is one of the certain functions that explain so that there is no misunderstanding in receiving information (KBBI, 2008). Some of the functions of explaining in the conversation between Mitsubishi car salesperson and consumers are as follows:

Dialogue 3

KL : Jadi, kalau kok mode tu beko oto tu lai masuak asuransi tu Buk? 'So, if that is the case, will the car get insurance, Mam?'

PMMP : Oto ko kalua kredit aman se ma Pak, beda jo tunai, kok tunai lain asuransinyo.

'If it is credit, its ok, Sir, it is different from cash, if cash it is different from the insurance.'

KL : Lai aman tu, Buk? 'Safe or not, mam?'

PMMP : Lai. All risk asuransinyo Pak. Kredit alah otomatis masuak asuransi. 'Yes, full of insurance, Sir. Credit buying is automatically getting insurance'.

KL : Beko takuiknyo anak ambo maantak garobak urang, tu mambayia ambo buk.

'Then, I'm afraid when my child hits wagons, and then I have to compensate it, Mam.' 
In the conversation above between KL and PMMP, vehicle insurance will be purchased. KL looks worried about the safety of the vehicle so that he asks about insurance to PMMP. KL asks will the car he bought getting insurance or not. PMMP responds to the question with an implicature speech.

The dialogue above contains the function of assertive implicature, namely explaining. A Mitsubishi car salesperson has the responsibility to ensure customer satisfaction. For this reason, PMMP tries to give information to $\mathrm{K}$ with an implicature speech. Based on the questions submitted by the KL, the PMMP response it by saying 'Oto ko kalau kredit aman se ma Pak, beda jo tunai, kok tunai lain asuransinyo'. From the speech, it appears that the PMMP wants to explain something to the KL. The statement explains that insurance for the purchase of the credit of the car will be different from cash insurance.

Dialogue 4

KL : Nyo lai lapang?

'The car is wide, isn't it?'

PMMP : Lah bisa lalok di balakang Pak, tampek duduak dibalakang nyo se lah sliding bisa dimajumundurkan

'It can be used to lay down behind, sir, the behind seat is sliding, it can be moved forward and backward'

KL : Yang di tangah? Yang dibalakang bana?

'How about in the middle? And how about on the backside?'

PMMP : Iyo, yang dibalakang sebana biaso, Pak.

'Yes, the one behind is still ordinary, Sir'

The conversation above discusses the specifications of the Mitsubishi Xpander. KL asks PMMP about the interior design of the car. As a $\mathrm{K}$, it needs to know the specifications of the product you want to buy. In the conversation, KL asks about the interior of the Mitsubishi Xpander. A PMMP is responsible for ensuring customer satisfaction. Therefore, she must provide information on all matters concerning the product so that the customers do not feel cheated.

Based on the questions submitted by KL, PMMP provides feedback in the form of implicature utterance 'Lah bisa lalok di balakang Pak, tampek duduak di balakangnyo se lah sliding, bisa dimajumundurkan.' The utterance implies that explaining the Mitsubishi Xpander is quite wide like the one KL wants. This is confirmed by the clause 'tampek duduak di balakangnyo se lah sliding, bisa dimajumundurkan' which is a description of the car's rear interior of Mitsubishi Xpander.

\subsubsection{Giving Opinion}

Giving opinions to submit a thought to the reader or the listener to be considered (KBBI, 2008). The following are some data that contain the function of giving an opinion.

Dialogue 5

PMMP : Pengen DP dibawah 100 ya, kalau nggak Adira ya MTF itu harganya hampirhampir sama tapi kalua MayBank atau BCA karena Bank jadi lebih murah. 'You want a down payment is 100 ? You can choose Adira or MTF, the 
cost almost the same, but if May Bank or BCA because it is a bank, it will be cheaper.'

KL : Dihitung dulu saja.

'just counted first'

PMMP : Abang kasih aja panjar dulu nanti kita coba minta press bunganya, mudahmudahan bisa.

'You can first give down payment, and then we try to ask to reduce the interest; hopefully, it can be.'

KL : Berarti harus dipanjar ya?

'It should be paid for a down payment, shouldn't it?'

PMMP : Mana tau nanti pas unit datang tarifnya naik, kan?

'It could be when the unit arrives, tariff goes up, right?'

KL wants to buy a Mitsubishi car, but he wants a down payment to finance the pay car. For this reason, he comes to the Mitsubishi showroom to negotiate with PMMP about leasing which will be used to pay the car. PM is responsible for ensuring $\mathrm{K}$ satisfaction. In this case, the PMM seeks to provide solutions to the wishes of $\mathrm{K}$ who want to use leasing with low interest.

Based on the data from the conversation above, it appears that PMMP suggests K uses several leasing such as ADIRA, MTF, Maybank, and BCA. Also, she suggests doing down payment first. Besides that, in this case, KL objects to PMM's suggestion and asks that should he make the down payment for the car. Moreover, the PMM responds with an implicature speech 'it could be when the unit arrives, tariff goes up.' The speech has a specific function, namely giving an opinion. Giving opinion in (KBBI, 2008) is to put a thought to the readers or the listeners to be considered. The PMM implicatures speech gives the opinion so that KL can consider making the down payment.

\subsection{Directive Function}

The directive function is a form of implicature function to produce an effect in the form of actions taken by speakers. After analyzing the data between Mitsubishi car salesperson and consumers in Padang, the directive function is demanding.

Demanding is one of the directive functions. Demanding can be defined as an act of asking harder or half requiring that have to be fulfilled (KBBI, 2008; Ansori et al., 2019). Here are some conversational implicatures between Mitsubishi car salespeople and consumers that contain demanding function.

Dialogue 6

The conversation in the dialogue above discusses the procedure of car indent. PMMP offers KP to indent the car first. After that, KP agrees to follow the indent procedures offered to him. Based on the previous data, PMMP promises to return the down payment if the car does not arrive within the specified time.

After analyzing the data above, it is found that the directive implicature function is demanding. Demanding in KBBI (2008) is an act of asking hard, or half requires that should be fulfilled. The response of KP 'ko yo bana ko Din $a^{\prime}$ is the implicature speech. KP indirectly intends to sue PMMP for entering its name in the indent list. Also, if it is related to the context of the speech conversation, it can imply 
that KP requires PMMP to fulfill its promise to return $100 \%$ of the down payment if the car does not arrive within the specified time.

\subsection{Commisive Function}

This function usually binds the speaker to action in the future. The commissive function tends to be fun. After analyzing the conversation dialog, it is found a commissive function such as advising, promising, and offering.

\subsubsection{Advising}

According to KBBI (2008), advising is an action to express something to be obeyed (done, carried out, so on.); propose (suggestions and so on). The following are some of the advising functions found in the conversation between Mitsubishi car salesperson and consumers in Padang.

\section{Dialogue 7}

$\mathrm{K} \quad$ : DP paliang randahnyo bara ko Buk?

'How much is the lowest down payment, Mam?'

PMM : Paliang randah biasonyo tujuah puluah Pak, tujuah puluahan lah randah bana ma.

'The lowest is usually seventy million, sir, about seventy million is already the lowest price ${ }^{\prime}$

$\mathrm{K} \quad$ : Tujuah puluah?

'Seventy million?'

PMM : Iyo

'Yes'

K : Jadi, kalau tujuah puluah, angsurannyo salamo ambiak 36 bulan bara tibonyo tu buk?

'So, if it is seventy million, how much is the installment of 36 months, mam?'

PMM : Kok alah pasti unitnyo beko diituangan dek leasing lai Pak

'If it is certain the car, it will be calculated by leasing, Sir.

K : Oh gitu buk

'I see, Mam'

The conversation above talks about the payment of a Mitsubishi Xpander. It is seen that KL asks about the lowest price of the down payment to the installment of the Mitsubishi Xpander for 36 months. Furthermore, PMMP provides the price information that is asked by KL.

After analyzing the data above, the directive function is found, namely advising. PMM has the responsibility for formulating a strategy to meet sales targets in the company. In the preparation strategy, PMM also has to be based on the procedures set by the company.

The data above shows KL asking about the installment price of a Mitsubishi Xpander for 36 months. PMMP responds with the clause 'Kok alah pasti unitnyo beko dituangan dek leasing lai Pak' implies PMMP cannot provide information about the price of the car for 36 months if it has not determined which car he wants. The speech also implies that PMM recommends that KL determine which car he will buy first before calculating the installment price of Mitsubishi for 36 months. 
This explains that PMMP is trying to formulate a strategy by advising KL to determine which car to buy so that it can calculate the installments that are questioned by KL. PMMP recommends that this is based on the procedure set by the company were to calculate the installments. $\mathrm{K}$ needs to determine the desired car first. Therefore, PMMP can accelerate the process of purchasing $\mathrm{K}$ cars so that they can meet the PMMP sales target.

\subsubsection{Promising}

Promising is one of the functions of commissive implicature. Promising is a form of expressing willingness and ability to do something for others (KBBI, 2008). The following are some PMM conversations with $\mathrm{K}$ that contain promising function.

Dialogue 8

PMMP : Tunggu sebentar, saya tanyakan dulu ya. 'Wait a minute, I ask first'

K1 : Iya 'Yes'

K2 : Jadi, kalau sudah habis masa asuransi saya, saya masuk kemari tetapi diskon, kalau ga diskon saya tetap disana.

'So, if my insurance period expires, I come here but get a discount if there is no discount, I stay in there.'

PAM : Nanti bisa hubungi saya saja Pak.

'You can contact me later, Sir,'

$\mathrm{K}$ wants a reduction in insurance prices offered by PAM. Speaker in conversation is one of the priorities. In this case, the priority of $\mathrm{K}$ is the most priority among other K. Priority of $\mathrm{K}$ is always making large amounts of transactions and subscribing for quite a long time. Based on this, PMM and PAM need to provide exceptional prices or special treatment to make him feel special. This is to maintain K.

In data 18, K2 requests a reduction in insurance prices to PAM. PAM responds by saying, 'you can contact me later, sir.' After analyzing the data above, it is found that the function of commissive implicature is promising. According to (KBBI, 2008), promising is a form of expressing willingness and ability to do something to others.

Based on the described context, PAM promises that he will give a discount to $K$. Through the conversation, the statement 'you can contact me later, sir' implies the willingness of PAM to give a discount or reduction in price to $\mathrm{K}$.

\subsubsection{Offering}

An offering is one of the speech act functions of commissive. The offering is to show something to others with the intention that it is bought, contracted, taken, used (KBBI, 2008). The following are some useful functions found in PMM conversation with $\mathrm{K}$ in Padang.

Dialogue 9

PMMP : Biasanya 70 Pak, rencanaya ambil cash atau kredit Pak? 'It is usually 70, Sir. Are you planning to take cash or credit, Sir?'

KP : Kredit

'Credit' 
PMMP : Lebih baik ambil yang Gls biar lebih cepat tapi kalau ibu ga buru-buru Exceed juga ga apa diinden aja dulu.

'It is better to take the Gls to be faster, but if you don't hurry, exceed can be indent first'

$\mathrm{KL} \quad$ : Inden berapa lama?

'How long is the indent?'

PMMP : Inden nya itu kita ga bisa mastiin berapa lama bang, kita tergantung alokasi yang kita dapat juga.

'We cannot be sure how long the indent, brother, we depend on the allocation that we get too'

$\mathrm{K}$ wants to buy a Mitsubishi Xpander so that he comes with his family to get information about the car. In the conversation, it appears that $\mathrm{K}$ and PMM are talking about the period of indent. $\mathrm{K}$ seems to object to the indenting process, which takes a long time.

In the dialog aforementioned, PMMP uses implication speech for conveying the intent. When it is connected to context, the dialogue is a form of action to show or offer something to $\mathrm{K}$ to consider. It can be concluded that it is an act of offering. In KBBI (2008), the offering is to show something to others with the intention that it is purchased, contracted, taken, used. Based on the understanding above, the conversation has the function of assertive implicature, namely offering.

Dialogues 10

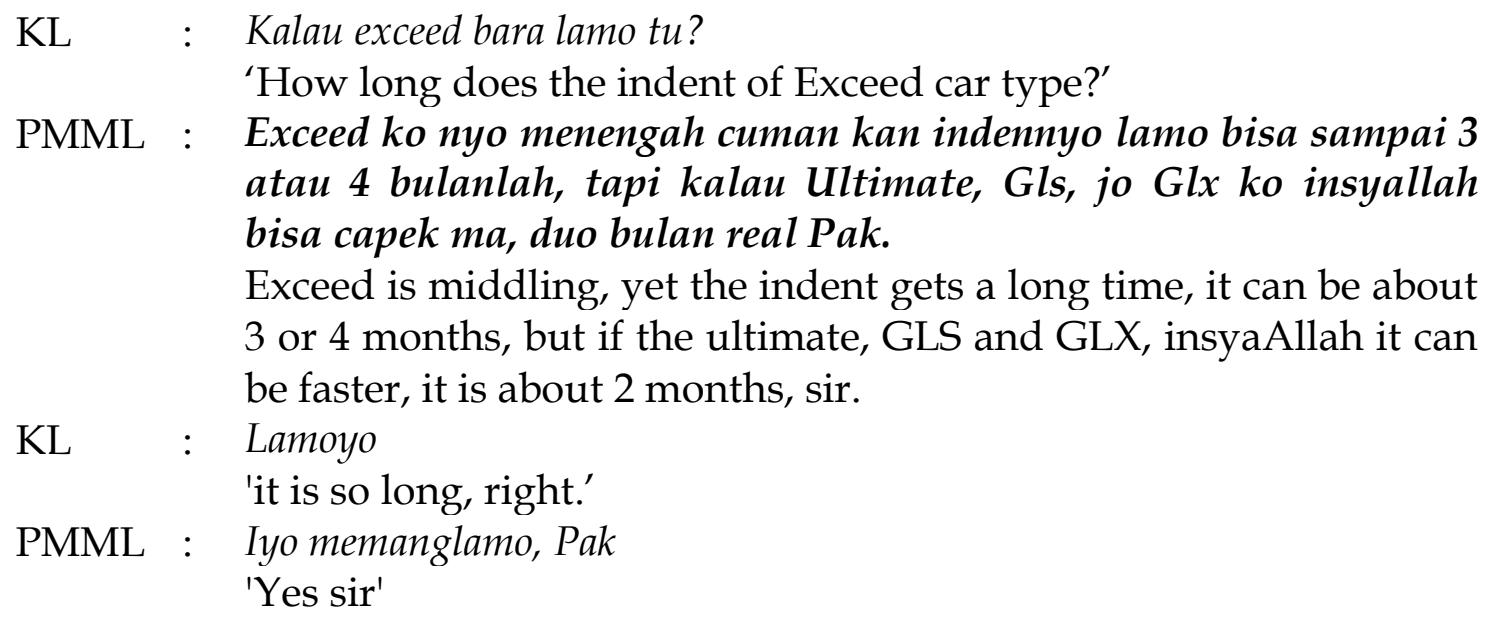

KL utters the conversation above to PMML. KL wants to buy a Mitsubishi Xpander but is still hesitant to determine the type of car that is right for him. Therefore, he comes to the showroom to get information. In the conversation above, it can be seen that KL is asking about the duration of the indentation of the Mitsubishi Xpander.

The question posed by $\mathrm{KL}$ about the period of the indentation of the Mitsubishi Xpander car was responded to by an opponent who spoke with an implication. This is what causes the formation of an implicature speech. Based on the responses given by PMML, it appears that the speaker wants to show something or a specific purpose to the opponent said.

After analyzing the conversation above, there is a commissive function, namely offering. It can be seen from the implicit meaning contained in dialogue 4 . In 
KBBI (2008), the offering is to show something to others with the intention that it is purchased, contracted, taken, used. In the dialog, it appears that PMML indirectly offers several types of Mitsubishi Xpander that do not need a long indent time, namely Mitsubishi Xpander Ultimate, Glx, and Gls. KL offers it to KL is interested in buying because the car does not require a long indent time.

\section{Conclusion}

Based on the results of data analysis on conversations between Mitsubishi cars salesperson and consumers in Padang, there are three pragmatic functions found in the conversation, namely 1) assertive such as expressing, explaining, and giving opinions. 2) directive such as demanding; and 3) commissive such as advising, promising, and offering. Form the several functions of implicature, the most dominant is assertive, such as expressing, explaining and giving opinions. It is due to the function that tends to be used to express and explain information about Mitsubishi cars needed by Mitsubishi consumers.

This research has enriched the language studies, especially in the pragmatic fields. This research is expected to enrich the readers' understanding of the implied meaning conveyed by the sales of the Mitsubishi cars and consumers indirectly. Furthermore, the study of conversational implicature between the sales of Mitsubishi cars and consumers in Padang City might help the reader in gaining the understanding of language phenomenon containing the implied meaning between the sales and consumer environment in Padang City. It is suggested that further research related to implicature can be conducted with other car brands' sales. Each brand may have its uniqueness that depicts their segment as well as the strategy of selling their product.

\section{References}

Adoma I. (2017). Grice's Conversational Implicature: A Pragmatics Analysis of Selected Poems of Audre Lorde. International Journal of Applied Linguistics $\mathcal{E}$ English Literature, 7(1), pp. 120-129.

Allott, N. (2018). Conversational Implicature. In Oxford Research Encyclopedia of Linguistics.

Anshori, S., Gunawan, F., \& Thahara, Y. (2019). Directive Expressions of The Main Characters in Green Book Movie.

Beeching, K. and Woodfield, H. (2015) Researching Sociopragmatic Variability. London: Macmillan Publishers Limited.

Departemen Pendidikan Nasional (2008) 'Kamus Besar Bahasa Indonesia Edisi Ketiga', in Kamus Besar Bahasa Indonesia Edisi Ketiga. Jakarta: Balai Pustaka.

Djajasudarma, T. F. (1993) Metode Linguistik: Rancangan Metode Penelitian dan Kajian. Bandung: Eresco.

Geoffrey L. (1993) Prinsip-Prinsip Pragmatik. Jakarta: Universitas Indonesia Press.

Gesit P. (2018) Mitsubishi Indonesia Dapat Pesanan 3,8 Ribu Unit Xpander dari Filipina dalam sebuah berita.

H.Paul., G. (1975). Log in and Conversation, in P.Cole and J.L Morgan eds, Syntax and Semantics, Vol 3. New York: Academic Press.

Harimurti K. (2008) Kamus Linguistik. Jakarta: PT.Gramedia Pustaka.

I Dewa P W. (1996) Dasar-Dasar Pragmatik. Yogyakarta: Andi. 
Ike R. (2013) Pragmatik:Kajian Tindak Tutur Permintaan Lintas Bahasa. Padang: Fakultas Ilmu Budaya Universitas Andalas.

John R S. (1969) Speech Acts: An Essay in the Philosophy of Language. Cambridge: Cambridge University Press.

Kravchenko, N. K. (2017). Indirect speech acts via conversational implicatures and pragmatic presuppositions. Cognition, communication, discourse, (14), 54-66.

Lexy M. (1998) Metode Penelitian Kualitatif. Bandung: PT.Remaja Rosda Karya.

Lubis, I. S. (2017). Conversational Implicatures of Indonesia Lawyers Club Program on TV ONE. CaLLs (Journal of Culture, Arts, Literature, and Linguistics), 1(2), 3244.

Slocum, B. G. (2016). Conversational implicatures and legal texts. Ratio Juris, 29(1), 23-43.

Stephen L. (1993) Principles of Pragmatics. Cambridge: Cambridge University Press.

Sudaryanto (2015) Metode dan Aneka Teknik Analisis Bahasa. Yogyakarta: Sanata Dharma University Press.

Wahyuningsih, Himah, dan R. (2017). Implikatur Percakapan dalam Stand Up Comedi 4'. Jurnal Bahtera, 2. 